\title{
PENGEMBANGAN DESAIN PEMBELAJARAN BIPA DARMASISWA PADA PEMBELAJAR TINGKAT MAHIR RENDAH
}

\author{
Prayitno Tri Laksono \\ Universitas Islam Malang \\ prayitno27@unisma.ac.id
}

\begin{abstract}
The Indonesian learning design of Indonesian Speakers of Other Language (ISOL) has unique characteristics. It depends on the level of the learner's initial language abilities, age, nationality, learning style, learning goals, and educational background of the learner. One of learning designs that has its own characteristics is at an advanced low level. It has different characteristics from learners at the low level. Characteristics of advanced low level learners already have sufficiently established language skills. To be able to improve their abilities, teachers must be able to design learning that can develop their Indonesian language skills like native speakers. This research was conducted in the Darmasiswa class at Malang Islamic University in 2019/2020. The learning design used is the ASSURE model, which is a learning design using an approach to classroom orientation.
\end{abstract}

Keywords: learning design, ISOL, advanced low

\section{PENDAHULUAN}

Pembelajaran Bahasa Indonesia bagi Penutur Asing atau sering disingkat dengan BIPA memiliki karakteristik yang berbeda dengan pembelajaran Bahasa Indonesia untuk orang Indonesia pada umumnya. Karakteristik pembelajaran BIPA ditentukan oleh berbagai faktor pendukung yang berasal dari faktor dalam diri pembelajar dan faktor di luar pembelajar. Pada faktor dari diri pembelajar, hal yang berpengaruh terhadap kegiatan pembelajaran BIPA adalah tingkat kemampuan pembelajar. Hal ini disebabkan oleh setiap tingkat kemampuan pembelajar BIPA memiliki karakteristik dan kebutuhan yang berbeda serta juga berpengaruh terhadap gaya belajarnya di dalam kelas.

Faktor lain yang berpengaruh terhadap pembelajaran BIPA adalah perbedaan motivasi, tujuan, dan minat yang dimiliki oleh masing-masing pembelajar saat belajar Bahasa Indonesia. Semakin tinggi tingkat kemampuan berbahasa mereka, semakin tinggi pula tingkat persiapan dan desain pembelajaran yang digunakan oleh guru di kelas. Perbedaan faktor-faktor tersebut berdampak kepada persiapan pembelajaran yang harus digunakan oleh pengajar saat melangsungkan pembelajaran di kelas BIPA. Materi ajar, strategi pembelajaran, dan bahan ajar yang digunakan oleh pengajar BIPA harus disiapkan dengan matang dan tepat sasaran agar tujuan dari pembelajaran itu tercapai. Oleh karena itu, pengajar BIPA diharapkan bisa menyusun desain pembelajaran secara sistematik dan menyeluruh sesuai dengan pendapat dari Syaiful (2005:136) yang mengatakan bahwa pengembangan desain pembelajaran harus dilakukan secara sistematik dengan menggunakan teori khusus untuk menjamin kualitas pembelajaran.

Dalam penelitian berjudul Pengembangan Desain Pembelajaran BIPA Darmasiswa pada Pembelajar Tingkat Mahir Rendah ini berfokus kepada mahasiswa BIPA yang berada pada tingkat mahir rendah dalam program Darmasiswa 2019/2020. Pemilihan mahasiswa tingkat mahir rendah program Darmasiswa sebagai subjek penelitian adalah untuk mengembangkan desain pembelajaran yang bisa digunakan khusus pada level tersebut. Pada tahun 2019/2020, terdapat empat 
mahasiswa yang berada pada tingkat mahir rendah, yaitu 1 mahasiswa asal Jepang, 1 mahasiswa asal Siriah, 1 mahasiswa asal Palestina, dan 1 mahasiswa asal Tajikistan. Berdasarkan kondisi di lapangan tersebut, pengajar BIPA harus menyiapkan pengembangan desain pembelajaran sesuai dengan karakterisktik pembelajar yang sudah berada pada tingkat mahir rendah, terutama dalam meningkatkan kemampuan mahasiswa agar bisa menjacapai tingkat mahir tinggi di akhir program selama 2 semester.

Desain pembelajara secara umum bisa diartikan ke dalam berbagai sudut pandang, yaitu sebagai disiplin, sistem, dan proses. Sebagai disiplin, desain pemebelajaran memaparkan mengenai hasil penelitian dan teori tentang strategi serta proses pengembangan pembelajaran dan pelaksanaannya. Sebagai sistem, desain pembelajaran adalah pengembangan sistem pembelajaran dan sistem pelaksanaanya yang termasuk sarana serta prosedur untuk meningkatkan mutu belajar. Sebagai proses, desain pembelajaran adalah rancangan untuk menuju pembelajaran yang bermutu melalui tahapan-tahapan analisis kebutuhan pada setiap aspek pembelajaran yang dimulai dari sederhana menuju kompleks.

Persiapan untuk membuat desain pembelajaran BIPA membutuhkan sebuah analisis kebutuhan awal terhadap pembelajar BIPA yang akan belajar Bahasa Indonesia. Mulai dari tingkat kemampuan, motivasi dan tujuan belajar, latar belakang negara, hingga pada usia pembelajar. Usia pembelajar BIPA yang beragam juga mendapat perhatian penuh demi kelancaran proses pembelajaran BIPA. Hal tersebut berhubungan dengan pendekatan, metode, teknik, dan media yang digunakan (Muliastuti, 2016: 4-5). Pendekatan dan metode pembelajaran yang diterapkan untuk pembelajar usia dini, remaja, dan dewasa, sangat berbeda. Pada usia dini misalnya, pendekatan model belajarnya akan cenderung ke tema-tema yang ringan dengan penyajian materi yang sederhana dan menyenangkan. Lain halnya dengan pendekatan untuk pembelajar usia dewasa yang lebih mengutamakan penyajian materi dengan menggunakan daya analisis lebih dalam dan kontekstual.

Selain memperhatikan usia pembelajar, faktor lain yang harus diperhatikan dalam persiapan desain pembelajaran BIPA adalah faktor budaya. Bagaimanapun juga, bahasa adalah salah satu unsur dalam masyarakat yang menggunakan bahasa tersebut. Jadi, penggunaan materi budaya dalam pembelajaran BIPA wajib hadir untuk mengaktualisasikan kecakapan pembelajar asing ketika menggunakan bahasa di masyarakat. Menurut Koentjaraningrat (dalam Ruskhan, 2007: 5) terdapat beberapa aspek budaya yang dapat dimanfaatkan dalam penyajian materi ajar BIPA, yakni (1) sistem peralatan dan perlengkapan hidup; (2) sistem mata pencarian hidup; (3) sistem; (4) bahasa; (5) kesenian; (6) sistem pengetahuan; dan (7) sistem religi.

$$
\text { Lestyarini (2012:3) juga }
$$

berpendapat bahwa identitas kultural Indonesia sudah seharusnya disertakan dalam pembelajaran. Dengan mempelajari konteks budaya, kehidupan sosial masyarakat Indonesia, dan norma-norma sebagai nilai entitas masyarakat, penutur asing dapat mempelajari karakter Indonesia yang merupakan syarat mutlak untuk mempelajari bahasa Indonesia.Hal tersebut tentunya cukup untuk dimengerti karena bahasa merupakan salah satu cermin jati diri masyarakat sehingga kajian dan pembelajarannya tidak akan dapat pernah dilepaskan dari kehidupan masyarakat itu sendiri.

Faktor lain selain budaya, hal terpenting dalam persiapan menyusunan 
desain pembelajaran BIPA adalah pelevelan atau tingkat kemampuan awal pembelejar BIPA. Berdasarkan kemampuannya, secara umum pembelajar BIPA terbagi menjadi tiga, yaitu tingkat pemula, tingkat menengah dan tingkat lanjut. Materi yang disuguhkan pun berbeda, disesuaikan dengan tingkatannya. Hal tersebut sesuai dengan apa yang disampaikan oleh Suyitno (2007: 68-69) bahwa materi bahasa yang dikembangkan dalam pembelajaran BIPA didasarkan pada tingkat kemampuan bahasa Indonesia pembelajarnya.

Pada desain pembelajaran dikenal berbagai model yang dijelaskan oleh para ahli. Salah satunya adalah desain pembelajaran model ASSURE, yaitu desain pembelajaran dengan menggunakan pendekatan pada orientasi kelas. Menurut Heincich et al (2005) model ini terdiri atas enam langkap tahapan kegiatannya, yaitu Analyze Learners, State Objectives, Select methods, media, and material, Utilitize media and materials, Require learner participation, dan Evaluate and revise. Dalam penelitian ini, tahapan-tahapan dalam ASSURE tersebut akan difokuskan pada pembelajar BIPA Darmasiswa yang berasal dari negara Timur Tengah. Keenam tahapan tersebut akan dijabarkan secara rinci sebagaimana berikut ini.

Tahapan pertama, yaitu analisis pelajar melalui tiga hal utama yang terdapat pada diri pembelajar asing, antara lain adalah ciri-ciri umum, kemampuan awal, dan gaya belajar. Dengan mengetahui ketiga hal tersebut lebih awal, pengajar BIPA akan lebih mudah dalam menentukan desain pembelajaran sesuai kebutuhan dan tingkatnya.

Tahapan kedua, yaitu menyatakan tujuan pembelajaran di tingkat mahir karena pembelajar pada tingkat ini sudah memiliki kemampuan awal yang mapan dan kompleks. Tujuan pembelajaran harus berfokus pada pengetahuan, kemahiran, dan sikap terhadap pengetahuan lanjutan yang akan dipelajari.

Tahapan ketiga, yaitu pemilihan metode, media, dan bahan ajar untuk BIPA tingkat mahir. Pada tahap ini, pengajar sudah harus tepat dalam memilih metode pembelajaran sesuai dengan analisis kebutuhan tahapan pertama dan kedua sebelumnya. Selain metode, pengajar juga harus menyiapkan media serta bahan ajar pendukung yang sejalan dengan metode tersebut agar kegiatan pembelajaran sesuai dengan tujuannya dan mencapai target yang direncanakan dalam desain pembelajaran.

Tahapan keempat, yaitu tahap penggunaan media dan bahan ajar yang telah dipilih sebelumnya. Terdapat lima langkah dalam penggunaan media yang baik, yaitu preview bahan, ketersediaan bahan, bahan sekitar, pembelajar, dan pengalaman.

Tahap kelima, yaitu tahap pengikutsertaan pembelajar di dalam kelas secara langsung dan berkelanjutan. Pembelajar asing pada tingkat mahir dituntut untuk bisa terlibat langsung dalam aktivitas pemecahan masalah, simulasi sebuah kondisi, pemajanan kemampuan bahasa secara langsung di masyarakat, dan presentasi ide atau temuan-temuan dari pembelajar selama tinggal di tengah-tengah kehidupan masyarakat Indonesia.

Tahap keenam, yaitu tahap penilaian dan revisi dari media dan bahan ajar yang disiapkan, strategi atau metode pembelajaran yang dilakukan, hingga pada capaian hasil belajar dari pembelajar asing di kelas. Tahap ini bertujuan untuk melihat dampak dari desain pembelajaran yang sudah dilakukan terhadap capaian pembelajaran yang ditargetkan sebelumnya.

\section{METODE}

$\begin{array}{ccr}\text { Pendekatan dalam } & \text { penelitian } \\ \text { berjudul } & \text { Pengembangan } & \text { Desain }\end{array}$ 


\section{Pembelajaran BIPA Darmasiswa pada} Pembelajar Tingkat Mahir Rendah ini adalah pendekatan penilitian kualitatif. Jenis penilitian yang digunakan adalah desain penelitian dan pengembangan, khususnya dalam pengembangan desain pembelajaran BIPA tingkat mahir. Dalam penilitian ini akan berfokus kepada aspek-aspek yang mendukung dalam kegiatan pembelajaran BIPA tingkat mahir, misalnya rencana pembelajaran, kebutuhan pembelajar, strategi pembelajaran, dan bahan ajar yang dibutuhkan. Berdasarkan penentuan aspekaspek tersebut, peneliti akan mengembangkan desain pembelajaran secara umum.

Pada penelitian pengembangan desain pemebelajaran ini, peneliti berperan sebagai pengamat serta pengajar BIPA Darmasiswa pada tingkat mahir. Dalam penelitian ini, peneliti menjadi pengumpul data, pengolah data, penganalisis data serta penyimpul hasil dari penelitian.

Data pada penelitian ini adalah semua informasi tertulis hasil studi dokumentasi, hasil observasi, hasil wawancara, dan hasil angket selama proses penelitian pengembangan desain pembelajaran berlangsung. Data difokuskan kepada kelas BIPA Darmasiswa pada tingkat mahir.

Sumber data pada penelitian ini adalah pengajar dan pebelajar BIPA Darmasiswa tingkat mahir yang berada pada program Daramasiswa 2019/2020 di Universitas Islam Malang. Selain itu, sumber data bisa didapatkan dari berbagai studi literasi yang berkaitan tentang penelitian pengembangan desain pembelajaran.

Langkah-langkah pengumpulan data pada penelitian ini sebagai berikut: (1) membuat daftar wawancara untuk digunakan sebagai alat penggalian informasi mengenai karakteristik mahasiswa tingkat mahir rendah secara personal kepada pembelajar dan pengajar; (2) membuat daftar angket untuk menghimpun informasi tentang analisis kebutuhan mahasiswa tingkat mahir rendah dalam belajar bahasa Indonesia; (3) membuat daftar observasi lapangan tentang aktivitas pembelajaran di kelas melalui strategi dan teknik yang digunakan oleh pengajar BIPA tingkat mahir; (4) menentukan subjek penelitian yaitu pengajar dan pebelajar BIPA tingkat mahir rendah yang berada di Universitas Islam Malang; (5) menentukan sumber data penelitian yaitu hasil wawancara, hasil angket, hasil observasi, dan hasil kajian dokumentasi; (6) menganalisis data sesuai dengan rumusan masalah; dan (7) menyimpulkan hasil temuan.

\section{HASIL DAN PEMBAHASAN}

Berdasarkan proses pengumpulan data yang dilakukan di lapangan, berikut adalah hasil temuan peneliti ketika mengambil data. Penyajian hasil penelitian akan dijabarkan dalam bentuk tabel dan penjelasan deskripsi kondisi real di lapangan. Berikut adalah penjelasan hasil penelitian.

Pertama, Karakteristik pada pembelajar Darmasiswa tingkat mahir rendah. Pada hasil wawancara personalitas pembelajar tingkat mahir rendah, peniliti mengumpulkan informasi terkait asal negara, latar belakang pendidikan, kebutuhan belajar, dan gaya belajar. Infomasi tersebut dapat dicermati pada Tabel 1. Karakteristik pembelajar Darmasiswa mahir rendah. 
Jurnal Filsafat, Sains, Teknologi, dan Sosial Budaya

Volume 26, Nomor 2, Oktober 2020

Tabel 1. Karakteristik Pembelajar Darmasiswa Mahir Rendah

\begin{tabular}{|c|c|c|c|c|c|}
\hline No & Nama & $\begin{array}{c}\text { Asal } \\
\text { Negara }\end{array}$ & $\begin{array}{c}\text { Latar Belakang } \\
\text { Pendidikan }\end{array}$ & Kebutuhan Belajar & Gaya Belajar \\
\hline 1 & ET & Jepang & Ilmu pertanian & $\begin{array}{l}\text { 1. Berkomunikasi bahasa } \\
\text { Indonesia dengan situasi } \\
\text { akademis } \\
\text { 2. Mendalami banyak istilah } \\
\text { terkait dengan pertanian di } \\
\text { Indonesia } \\
\text { 3. Melanjutkan penelitian terkait } \\
\text { pertanian di Indonesia } \\
\text { 4. Mempelajari budaya di } \\
\text { Indonesia secara umum }\end{array}$ & $\begin{array}{l}\text { 1. Menerima semua strategi } \\
\text { 2. Audio visual } \\
\text { 3. Cenderung pendiam } \\
\text { ketika tidak paham } \\
\text { 4. Mudah menghafal } \\
\text { 5. Tipe praktikal }\end{array}$ \\
\hline 2 & SL & Siriah & $\begin{array}{l}\text { Desain interior } \\
\text { dan Teknik Sipil }\end{array}$ & $\begin{array}{l}\text { 1. Melanjutkan studi S2 di } \\
\text { Indonesia } \\
\text { 2. Mengambil jurusan S2 desain } \\
\text { interior } \\
\text { 3. Hidup di lingkupan akademis } \\
\text { dan masyarakat lokal }\end{array}$ & $\begin{array}{l}\text { 1. Memiliki privasi diri yang } \\
\text { kuat } \\
\text { 2. Tidak bisa cepat, harus } \\
\text { dituntun pelan-pelan } \\
\text { 3. Komitmen dengan aturan } \\
\text { 4. Pembelajar cepat } \\
\text { 5. Cenderung harus fokus }\end{array}$ \\
\hline 3 & SM & Tajikistan & Bahasa Inggris & $\begin{array}{l}\text { 1. Berkontribusi dalam bidang } \\
\text { sukarelawan } \\
\text { 2. Mendidik anak kecil untuk } \\
\text { belajar bahasa asing, } \\
\text { khususnya Inggris dan } \\
\text { Indonesia } \\
\text { 3. Mengembangkan diri sebagai } \\
\text { penutur bahasa Indonesia yang } \\
\text { mahir di tingkat akademik } \\
\text { 4. Mempelajari budaya di } \\
\text { Indonesia dalam bidang tarian } \\
\text { tradisional }\end{array}$ & $\begin{array}{l}\text { 1. Menerima semua strategi } \\
\text { 2. Aktif dalam berbicara } \\
\text { 3. Aktif reaktif terhadap } \\
\text { materi dari guru } \\
\text { 4. Mudah menghafal dan } \\
\text { cepat tanggap } \\
\text { 5. Tipe Praktikal }\end{array}$ \\
\hline 4 & ML & Palestina & $\begin{array}{l}\text { Bahasa Asing } \\
\text { Oriental }\end{array}$ & $\begin{array}{l}\text { 1. Menguasai bahasa Indonesia } \\
\text { mahir } \\
\text { 2. Mendapatkan beasiswa S2 } \\
\text { 3. Menambah jejaring mahasiswa } \\
\text { asing di Asia Tenggara }\end{array}$ & $\begin{array}{l}\text { 1. Tipe pembelajar audio } \\
\text { 2. Tidak bisa cepat, harus } \\
\text { dituntun pelan-pelan } \\
\text { 3. Kutang komitmen dengan } \\
\text { aturan kelas } \\
\text { 4. Sulit dalam bahasa yang } \\
\text { produktif } \\
\text { 5. Cenderung harus fokus }\end{array}$ \\
\hline
\end{tabular}


Berdasarkan hasil data yang sudah dirangkum dalam Tabel 1 tersebut dapat dipaparkan pembahasannya sebagai berikut.

(1) Asal negara pembelajar asing dalam proram BIPA Darmasiswa 2019/2020 dapat menjadi tolok ukur awal bagaimana gaya belajar yang dilakukan oleh mereka ketika di dalam kelas. Mahasiswa ET yang berasal dari Jepang secara umum memiliki perbedaan karakteristik dengan mahasiswa lain yang berasal Asia Timur dan Asia Tengah, yaitu SL, SM, dan ML. Hal yang sangat terlihat berbeda adalah bentuk reaksi pembelajar terhadap strategi pembelajaran yang digunakan oleh guru di kelas. Secara geografis, lokasi negara asal mereka berjauhan satu dengan yang lainnya. Hal inilah yang akan membuat perbedaan dengan gaya belajar yang biasa digunakan dalam kelas-kelas di negara mereka masingmasing. Akan tetapi, untuk mahasiswa yang bernama SL dan ML yang berasal dari Siriah dan Palestina (negara Timur Tengah) memiliki kemiripan dalam beberapa hal. Kemiripan ini didukung oleh budaya yang sama dan letak geografis yang berdekatan antara satu dengan lainnya. Dengan demikian, asal negara mahasiswa sangat berpengaruh dalam penyusunan desain pembelajaran yang tepat terutama dalam kelas heterogen seperti program Darmasiswa 2019/2020 di Universitas Islam Malang ini. Guru atau pengajar BIPA dalam program kelas heterogen seperti ini harus melakukan pemetaan latar belakang berdasarkan asal negara agar pelaksanaan pembelajaran bisa tercapai dengan baik sesuai tujuan.

(2) Latar belakang pendidikan terakhir mahasiswa dalam program Darmasiswa juga menjadi pertimbangan sebelum menyusun desain pembelajaran di kelas. Hal ini bertujuan untuk memudahkan pengajar ketika menyusun kisi-kisi materi kebutuhan belajar bahasa dan budaya di kelas. Penjajagan latar belakang pendidikan terakhir pembelajar asing ini dapat memudahkan pengajar dalam menyiapkan susunan materi ajar yang memiliki konten sesuai dengan peminatan setiap pembelajar di kelas. Misalnya mahasiswa yang bernama ET memiliki latar belakang pendidikan dalam bidang pertanian, mahasiswa tersebut akan bisa dengan mudah memfokuskan pembelajaran bahasa Indonesia ketika guru menyampaikan materi dengan konten yang berkaitan dengan pertanian di Indonesia pada khususnya. Materi kelas bahasa Indonesia di tingkat mahir rendah bisa berupa pembahasan konten yang lebih dalam daripada sekadar pembahasan mengenai bahasa itu sendiri. Pembelajar tingkat mahir awal dapat memperdalam pembelajaran bahasa melalui konten keilmuan yang dimiliki berdasarkan latar belakang pendidikan terakhir mereka. Dengan demikian, pembelajar asing bisa mengungkapkan bidang keilmuan mereka dalam bahasa Indonesia yang tepat sesuai dengan kedalamann diksi dan konteksnya.

(3) Kebutuhan belajar juga dapat dijadikan rujukan sebelum menyusun desain pembelajaran tingkat mahir rendah. Dalam hal ini masih berkesinambungan dengan latar belakang pendidikan terakhir yang dimiliki oleh pembelajar asing program Darmasiswa 2019/2020 di Universitas Islam Malang. Mahasiswa bernama ML misalnya, memiliki kebutuhan belajar untuk bisa berkomunikasi dalam bahasa Indonesia secara mahir dan akademis karena dia ingin melanjutkan studi lanjut beasiswa S2 di Indoensia. Kondisi seperti ini menuntut guru untuk mendesain pembelajaran dalam kelas yang lebih akademis dengan menggunakan tingkat kesulitan setara dengan mahasiswa S2 regular. Jika saja pengajar tidak bisa menangkap kebutuhan ML dengan baik, mahasiswa ML akan kesulitan nanti saat 
akan mengikuti kualifikasi tes beasiswa S2 di Indonesia. Contoh lain, mahasiswa bernama SM memiliki kebutuhan lain selain belajar bahasa Indonesia di kelas. Dia memiliki kebutuhan lain, yaitu belajar budaya Indonesia dalam bidang seni tari. Ketika guru melakukan penjajagan/analisis kebutuhan terhadap SM lebih awal, guru akan bisa menentukan desain pembelajaran di luar kelas. Pembelajaran BIPA tidak sekadar dalam bidang keilmuan bahasa, tetapi juga harus mengakomodasi pembelajaran budaya. Tujuan dari perancangan desain pembelajaran ini adalah bisa memfasilitasi kebutuhan pembelajar BIPA secara komprehensif agar bisa mencapai pembelajaran yang efektif.

(4) Gaya belajar termasuk dalam karakteristik pembelajar yang juga harus diperhatikan oleh setiap pengajar sebelum mengembangkan desain pembelajaran BIPA pada tingkat mahir rendah. Pemetaan gaya belajar mahasiswa asing bisa diidentifikasi sejak minggu awal pembelajaran di kelas. Pengajar bisa menyiapkan angket awal mengenai gaya belajar yang biasa dilakukan oleh mahasiswa ketika di negara mereka masing-masing. Walau pengajar tidak harus memfasilitasi semua model gaya belajar yang dimiliki oleh mahasiswa asing, guru tetap bisa menyiapkan strategi yang dapat meminimalisasi ketidakberterimaan model pengajaran yang dilakukan terhadap mahasiswa yang memilki gaya belajar berbeda-beda antara satu dengan yang lainnya. Peneliti mendapatkan gambaran secara umum gaya belajar mahasiswa berdasarkan studi lapangan secara langsung dan hasil dari angket yang diberikan kepada mahasiswa asing tersebut. Oleh karena dalam kelas Darmasiswa 2019/2020 di Universitas Islam Malang ini terdapat empat mahasiswa dari empat negara yang berbeda serta dengan gaya belajar yang berbeda pula, pengajar sepatutnya sudah harus memetakan gaya belajar mereka secara cermat.
Pemetaan gaya belajar ini akan memberikan kesempatan kepada pengajar untuk melakukan eksplorasi dalam penentuan strategi pembelajaran yang efektif dan bisa mencapai target pembelajaran. Mahasiswa bernama SL misalnya dengan gaya belajar yang cenderung memiliki privasi tinggi dan kritis harus diberikan perlakuan berbeda dengan mahasiswa yang bernama SM yang cenderung berkepribadian terbuka dengan gaya belajar yang fleksibel. Mencermati perbedaan gaya belajar pada mahasiswa dapat memberikan ruang yang luas untuk pengajar ketika melaksanakan pembelajaran di kelas BIPA.

Selain karakteristik kelas BIPA yang lebih fleksibel dengan kurikulum, kelas BIPA juga mempunyai tantangan tersendiri dalam penyikapan gaya belajar yang dibawa oleh mahasiswa di dalam kelas. Mahasiswa dan guru/pengajar harus saling beradaptasi dalam mempertemukan gaya belajar yang berbeda antarmahasiswa dan pengajar. Materi yang disiapkan oleh guru/pengajar BIPA bisa jadi tidak akan sampai dengan baik dan tidak bisa diterima dengan baik hanya karena guru tidak memahami gaya belajar tiap-tiap mahasiswanya. Bisa jadi dalam satu materi dapat disampaikan dengan berbagai strategi atau pendekatan yang berbeda karena menyesuaiakan gaya belajar mahasiswanya. Apabila kelas BIPA yang diselenggarakan adalah kelas homogen atau dengan jenis peserta yang sama asalnya, pembelajaran bisa didesain dengan mudah karena gaya belajar yang hampir sama pula antar mahasiswa. Namun, ketika kelas BIPA yang diselenggarakan adalah kelas heterogen yan berasal dari negara berbeda dan gaya belajar yang berbeda pula, pengajar harus mendesain pembelajarannya secara cermat supaya penyampaian materi dapat dilakukan secara efektif. Pada akhirnya, analisis karakter pembelajar bisa menjadi acuan awal dalam rangka penyusunan desain pembelajaran yang ideal. 
Kedua, Analisis kebutuhan mahasiswa Darmasiswa tingkat mahir rendah. Berikutnya, setelah peneliti menganalisis dan membahas hasil penelitian dalam hal karakteristik mahasiswa BIPA progam Darmasiswa 2019/2020 di Unisma, berikut akan dijabarkan secara rinci mengenai hasil analisis kebutuhan mahasiswa Darmasiswa tingkat mahir rendah.

Dalam analisis kebutuhan mahasiswa Darmasiswa tingkat mahir rendah ini, peneliti membagi ke dalam empat kebutuhan pembelajaran selama program berlangsung. Keempat kebutuhan tersebut adalah (1)kebutuhan terkait pembelajaran kebahasaan, (2)kebutuhan terkait keterampilan bahasa, (3)kebutuhan pengembangan diri di lingkungan, dan (4) kebutuhan pembelajaran budaya. Hasil dan pembahasan dari keempat kebutuhan mahasiswa adalah sebagai berikut ini.

(1) Kebutuhan pembelajaran kebahasaan.

Berdasarkan hasil angket yang sudah disebarkan kepada mahasiswa dan pengajar di kelas Darmasiswa tingkat mahir rendah, terdapat $92 \%$ responden menjawab kebutuhan mengenai tata bahasa lanjut harus diajarkan di dalam kelas BIPA. Hal ini sejalan dengan kurikulum BIPA tingkat mahir, kemampuan tata bahasa lanjut harus diajarkan di dalam kelas dengan didesain dalam berbagai model pembelajaran yang sesuai kebutuhan. Tata bahasa lanjut yang dapat diajarkan dalam tingkat mahir berupa materi proses morfologis kompleks, yaitu pengimbuhan konfiks dan klofiks yang sudah bermakna abstrak. Selanjutnya, tata bahasa dalam bentuk fonologi dapat didesain berupa pemantapan proses ucapan pada articulator mahasiswa asing agar mendekati bunyi ucapan penutur jati. Sebagaimana tuntutan pada tingkat mahir, mahasiswa BIPA wajib bisa mengucapkan berbagai bentuk bunyi yang sesuai dengan pengucapan dari penutur jati di Indonesia, khususnya penutur jati yang standard. Selain penguatan tata bahasa pada ranah morfologi dan fonologi, mahasiswa juga membutuhkan materi lanjut terkait dengan ilmu semantik/pemaknaan hal-hal abstrak dalam bahasa Indonesia. Salah satu penanda dari tingkat mahir adalah mahasiswa mampu menangkap makna dalam bentuk satuan kata atau kalimat dengan kosa kata/diksi yang abstrak ujudnya. Hal ini manandakan mahaiswa tingkat mahir sudah mampu menghubungkan antara satuan kata/diksi dengan konteks yang sedang dia alami.

Kebutuhan terhadap tata bahasa tersebut harus dituangkan dalam desain pembelajaran selama pelaksanaan program agar ketercapaian pembelajaran tata bahasa dapat diukur dengan bentuk evaluasi yang sudah disiapkan untuk menunjukan peningkatan level kebahasaan mereka di akhir program.

(2) Kebutuhan keterampilan berbahasa.

Keterampilan berbahasa Indonesia juga menjadi tujuan utama selain penguasaan tata bahasa bagi mahasiswa asing BIPA program Darmasiswa 2019/2020 di Universitas Islam Malang. Pembelajaran yang bertujuan untuk meningkatkan keterampilan berbahasa Indonesia hendaknya dirancang sesuai dengan tingkat kemampuan bahasa mahasiswa asing. Semakin tinggi tingkat kebahasaan yang dikuasai oleh mahasiswa asing, maka semakin kompleks pula keterampilan berbahasa yang harus diajarkan kepada mereka.

Pada hasil pengambilan data melalui interviu dengan pengajar BIPA program Darmasiswa 2019/2020 di Universitas Islam Malang teradapat data yang menyatakan bahwa tim guru sepakat menggunakan model pembelajaran diskrit atau terpisah berdasarkan jenis keterampilan yang terdapat dalam bahasa Indonesia, yaitu keterampilan menyimak, berbicara, membaca, dan menulis. Keempat keterampilan tersebut dianggap penting oleh 
pengajar BIPA untuk diajarkan keseluruhan dan diajarkan secara terpisah. Pemisahaan materi sesuai keterampilan bertujuan untuk menajamkan keterampilan berbahasa mereka yang disertai pula dengan muatan materi konten sesuai bidang tiap-tiap mahasiswa. Pada data interviu, $100 \%$ tim guru setuju dengan system pemisahan keterampilan tersebut. Selain meningkatkan keterampilan berbahasa mahasiswa, guru akan dapat dengan leluasa untuk mengaktualisasikan kondisi lingkungan penutur jati bahasa Indonesia kepada mahasiswa.

Guru BIPA kelas mahir rendah mengungkapkan bahwa pada setiap keterampilan berbahasa memiliki karakteristik tersendiri meskipun saling berhubungan satu dengan yang lainnya. Hal tersebut juga memudahkan guru untuk menentukan target pada tiap-tiap keterampilan berbahasa Indonesia, misalkan pada keterampilan meyimak yang diajarkan kepada mahasiswa adalah berbagai jenis simakan yang ada di lingkungan penutur jati disajikan di dalam pembelajaran kelas BIPA agar mahasiswa mampu memahami berbagai jenis simakan tersebut. Simakan-simakan yang ada di lingkungan asli akan sedikit meyulitkan mahasiswa asing jika guru tidak pernah mengenalkan dan menghadirkan contohnya di dalam kelas.

Pada keterampilan berbicara pun demikian, guru melatih mahasiswa asing untuk dapat berbicara dalam berbagai topik yang sering digunakan oleh penutur jati di lingkungan mereka tinggal. Topikk untuk mahasiswa tingkat mahir rendah tentunya sudah tidak sama dengan topik pada mahasiswa tingkat lainnya. Pada tingkat ini, mahasiswa sudah berlatih dengan topiktopik dari berbagai bidang keilmuan yang bersifat kompleks dan akademis. Mahasiswa asing sudah hendaknya dapat mengungkapkan ide pikiran mereka dalam bentuk berbagai kegiatan berbicara yang beragam, misalnya dalam bentu talk show, pidato, bercerita, dan bentuk lainnya. Aktivitas kelas yang dapat mengakomodasi kebutuhan seperti tersebut bisa dilaksanakan dengan maksimal dalam bentuk pembelajaran diskrit.

Pada keterampilan membaca, guru bisa mengakomodasi kebutuhan mahasiswa asing dalam berbagai bentuk pembelajaran. Pembelajaran yang dipilih oleh tim guru kelas mahir rendah dalam kelas Darmasiswa 2019/2020 ini adalah menyajikan berbagai jenis bacaan, contohnya adalah bacaan popular nonfiksi, bacaan ilmiah, dan bacaan yang berasal dari karya fiksi. Segala jenis bacaan tersebut dapat diajarkan kepada mahasiswa berdasarkan urutan kesulitan dan prioritas kebutuhan. Guru dapat menyusun rencana pembelajaran dalam keterampilan membaca berdasarkan kebutuhan mahasiswa di kelas tersebut karena setiap kelas akan memiliki kebutuhan yang khas bergantung latar belakang pembelajarnya.

Hasil dari wawancara dengan tim guru kelas mahir rendah menunjukan bahwa bacaan yang disajikan dalam pembelajaran berdasarkan peminatan mahasiswa dan keterpakaian di lingkungan mereka tinggal di Indonesia. Bentuk bacaan juga disesuaikan dengan urutan kesulitan yang terdapat dalam bacaan tersebut. Guru dapat menyajikan bacaan ringan di awal pembelajaran kelas membaca, misalnya mahasiswa diajak untuk membaca bigrafi ringkas dari tokoh-tokoh terkenal di Indonesia atau bacaan mengenai peristiwa penting yang terdapat di Indonesia. Hal ini bisa sekaligus sebagai cara untuk memasukan konteks budaya di dalam pembelajaran kelas membaca.

Pada kelas keterampilan membaca di program Darmasiswa 2019/2020, guru sudah menerapkan hal tersebut dengan cara menggunakan hasil analisis latar belakang peminatan tiap-tiap mahasiswa untuk menentukan jenis bacaan yang akan 
digunakan di dalam kelas. Hal ini sangat membantu mahasiswa asing dalam memahami konteks bacaan yang dibaca karena mereka sekaligus dapat memahami bidang mereka dalam sajian bacaan bahasa Indonesia.

Kelas keterampilan terakhir adalah keterampilan menulis. Keterampilan menulis menjadi salah satu yang paling kompleks dari keterampilan yang lain karena menuntut mahasiswa dapat mengombinasikan semua keterampilan yang sudah mereka punya dalam bentuk tulisan. Hasil observasi tulisan dan wawancara dengan tim guru kelas mahir rendah menunjukan bahwa pada tulisan mahasiswa terdapat indikator yang dapat diteliti lebih lanjut mengenai keterkaitan keterampilan membaca dan menyimak mereka. Tim guru menggunakan hasil tulisan mahasiswa asing dalam pemetaan tingkat pengetahuan mereka serta melihat korelasi yang ada antara keterampilan menulis, membaca, dan menyimak.

Pemilihan materi menulis dalam kelas meggunakan pendekatan topik seperti halnya pada keterampilan lain. Hasil wawancara menunjukan bahwa mahasiswa mampu menyusun komposisi dalam bentuk tulisan dalam berbagai topik yang disajikan oleh guru. Selain itu, variasi pilihan tulisan yang harus dikerjakan oleh mahasiswa juga telah disesuaikan dari tingkat termudah ke tingkat kompleks. Pada tingkat mahir awal, mahasiswa sudah dituntut untuk dapat menuliskan berbagai ide dalam bentuk yang kasual maupun bentuk formal. Perangkaian kalimat-kalimat dalam tulisan mahasiswa juga harus lebih akurat agar kosa kata yang sudah dimiliki dapat digunakan secara tepat.

(3) Kebutuhan pengembangan diri di lingkungan.

Dalam analisis kebutuhan pengembangan diri mahasiswa asing dalam lingkungan mereka tinggal juga harus diperhatikan dengan seksama oleh guru ketika menyusun desain pembelajaran mahasiswa pada tingkat mahir rendah. Pengembangan diri mahasiswa asing sangat penting untuk dilakukan selain pengembangan keakademisan mahasiswa di dalam kelas. Bentuk pengembangan diri yang dilakukan oleh guru hendaknya mengacu kepada pengembangan kecakapan hidup mahasiswa tersebut terhadap lingkungan tempat mereka tinggal di Indonesia. Hal ini akan sangat bermanfaat bagi kehidupan mahasiswa asing di tengahtengah penutur jati.

Hasil observasi lapangan dan wawancara dengan mahasiswa bernama ET, SL, SM, dan ML menunjukan mereka sangat menginginkan untuk bisa mengaktualisasikan kemampuan berbahasa Indonesia di dalam lingkungan mereka tinggal. SL misalnya, dia menyebutkan bahwa ingin bisa mengajarkan bahasa Arab dengan pengantar bahasa Indonesia kepada mahasiswa di Universitas Islam Malang. Lain halnya dengan SM, dia menyebutkan lebih ingin mengikuti kegiatan sukarelawan dalam bidang motivasi pendidikan di Indonesia pada umumnya dan di Kota Malang pada khususnya. SM sudah pernah mengikuti beberapa kegiatan sukarelawan di SD, SMP, dan SMA di Jawa Timur dalam bidang motivasi pendidikan. SM memberikan motivasi kepada siswa-siswa dengan menggunakan bahasa Indonesia yang sudah dia pelajari di kelas.

Sementara itu, ET dan ML ingin dapat mengembangkan kemampuan dirinya dalam bentuk peningkatan komunikasi secara akademis dan informal dengan berbagai lapisan masyarakat yang berbeda. ET dan ML juga telah menyebutkan dalam wawancara bahwa mereka tertarik untuk bisa melakukan komunikasi secara intensif dengan tingkatan masyarakat yang berbeda.

Melihat kondisi mahasiswa yang seperti itu, tim guru harus memasukan kebutuhan pengembangan diri dalam desain pembelajaran yang berfokus di luar kelas 
agar kemampuan berbahasa Indonesia mereka bisa diaktualisasikan secara nyata di lingkungan tempat mereka tinggal. Hal ini sejalan dengan prinsip pembelajaran BIPA bahwa belajar bahasa adalah belajar bagaimana cara menggunakannya dalam lingkungan nyata bukan belajar tentang apa itu bahasa.

(4) Kebutuhan pembelajaran budaya.

Kebutuhan terakhir yang juga harus dimasukan dalam rencana pengembangan desain pembelajaran kelas BIPA pada tingkat mahir rendah adalah pembelajaran budaya. Dalam ini, pembelajaran budaya yang bisa dimasukan sebagai materi pembelajaran di kelas tidak hanya budaya yang berupa hasil cipta karya manusia, tetapi juga budaya yang tak berujud cipta karya. Hasil wawancara dengan mahasiswa dan guru BIPA kelas mahir rendah di program Darmasiswa 2019/2020 di Universitas Islam Malang menunjukan bahwa dari keempat mahasiswa memiliki kebutuhan pembelajaran budaya yang berbeda.

ET menuturkan bahwa pembelajaran budaya yang ingin dia pelajari adalah terkait dengan budaya berujud seperti batik, seni lukis, dan topeng. Selain itu ET juga menyebutkan bahwa budaya ramah tamah Indonesia menjadi penting untuk disajikan dalam kelas agar dia bisa segera beradaptasi tanpa harus menyakiti orang lain ketika berkomunikasi.

Sementara itu SM memiliki target untuk bisa belajar budaya dalam bentuk tarian khas Indonesia karena dia harus membuat pertunjukan tarian Indonesia di KBRI Tajikistan saat sudah kembali ke negaranya. Berdasarkan hal tersebut, guru harus merancang kelas budaya tari selain kelas bahasa Indonesia agar kebutuhan budaya mahasiswa dapat terfasilatsi juga.

Berbeda dengan hasil wawancara dari SL dan ML, mereka tidak memiliki kekhususan dalam mempelajari budaya
Indonesia. Hal ini disebabkan oleh latar belakang negara asal mereka, yaitu Timur Tengah. Kedua mahasiswa ini cenderung tidak mempelajari budaya secara mendalam. Akan tetapi, mereka masih mau untuk mencoba untuk mengenal budaya Indonesia yang berujud, misalnya belajar membatik. Pada hasil wawancara dengan tim guru menunjukan berbagai benturan antara budaya asal negara mereka dengan budaya Indonesia ketika mereka mempelajarinya. Oleh karena itu, guru perlu menganilisis kebutuhan awal terhadapat budaya agar tidak menyebabkan kesalahpahaman antarmahasiswa dan guru ketika haru belajar budaya.

Ketiga, teknik pembelajaran mahasiswa di kelas Darmasiswa tingkat mahir rendah. Berdasarkan hasil pengumpulan data dari wawancara dengan tim guru dan observasi kelas BIPA Darmahsiswa 2019/2020 tingkat mahir rendah, tim guru menggunakan beberapa strategi pembelajaran yang digunakan selama proses pembelajaran. Strategi tersebut antara lain: (a) penubian, (b) bermain peran, (c) celup total, dan (d) pemodelan. Berikut dijelaskan secara rinci dari masing-masing teknik pembelajaran tersebut.

Pertama, teknik penubian dilakukan guru ketika memberikan kosa kata baru yang bersifat morfofonemis. Teknik ini digunakan untuk memudahkan mahasiswa dalam mengucapkan sebuah kata kompleks secara tepat, misalnya kata [menyengsarakan], [ngomong-ngomong], [perseteruan], dan [mengasingkan]. Keempat kata tersebut akan sulit diucapkan oleh mahasiswa jika tidak diberikan contoh yang berulang oleh guru. Setelah diberikan contoh, guru juga harus menubikan pengucapan beberapa kali kepada mahasiwa sampai mereka dapat mengucapkan secara tepat. Salah satu indikator dari kelas mahir rendah adalah mahasiswa dapat mengucapkan kata 
kompleks secara tepat dan memahaminya dengan baik.

Kedua, teknik bermain peran juga diterapkan dalam kelas berbicara. Teknik ini dianggap paling efektif oleh tim guru kelas mahir rendah. Dalam kelas berbicara, mahasiswa dituntut untuk bisa menggunakan kemampuan berbicaranya di lingkungan asli. Sebelum mereka bisa berbicara sesuai dengan berbagai konteks di lingkungan asli, guru menyiapkan berbabagi scenario teknik pembelejaran bermain peran sesuai dengan situasinya. Mahasiswa tingkat mahir rendah dituntut untuk mampu mengaktualisasikan kemampuanya dengan lancar atau tidak gagap. Untuk mencapai hal tersebut, guru menyiapkan berbagai jenis konteks berbicara dan mahasiswa bermain peran sesuai konteks tersebut secara tepat.

Ketiga, teknik celup total yang digunakan oleh tim guru sudah diterapkan dalam kelas mahir rendah bahkan teknik ini bisa diterapkan pula pada tingkat pemula awal agar mempercepat proses pemerolehan bahasa kedua mahasiswa asing saat belajar di dalam kelas. Hasil wawancara dengan tim guru menunjukan bahwa teknik celup total mempermudah mahasiswa untuk memahami kosa kata baru dalam bahasa Indonesia tanpa melalui proses penerjemahan bahasa. Teknik ini menuntut mahasiswa asing dalam kelas untuk berbicara penuh dalam bahasa Indonesia dan tidak diperkenankan melihat kamus ketika mereka kesuliatan memahami sebuah kata ataupun kalimat.

Keempat, teknik terakhir yaitu teknik pemodelan. Mahasiswa tingkat mahir rendah dituntut untuk dapat mendekati cara berbahasa penutur jati. Untuk mencapai tujuan tersebut, guru menggunakan teknik pemodelan yang nyata di lapangan agar mahasiswa asing mampu mengekspresikan kemampuan berbahasa mereka seperti penutur jati. Pemodelan dapat digunakan dalam semua jenis keterampilan berbahasa karena semua keterampilan berbahasa tersebut terdapat di dalam lingkungan penutur jati secara komprehensif. Dalam hasil analisis studi lapangan, guru menggunakan pemodelan penutur dengan dialeg bahasa Jawa ketika berbicara bahasa Indonesia. Pemodelan ini tentunya bergantung pada lingkungan tempat mereka tinggal agar bisa menyesuaikan dengan cara berbicara yang akan digunakan oleh mahasiswa asing di lingkungan tersebut. Teknik pemodelan juga bisa digunakan dalam gaya tulis penutur jati yang berupa tulisan ringan di media social. Mahasiswa akan terbantu ketika mereka dapat menulis sesuai dengan gaya penutur jati.

Keempat, bentuk evaluasi pembelajaran yang digunakan pada kelas mahir rendah. Jenis evaluasi pembelajaran yang digunakan oleh guru di kelas BIPA Darmasiswa 2019/2020 mahir rendah adalah evaluasi berbasis tes dan nontes. Evaluasi berbasis tes yang digunakan adalah dalam bentuk tes komprehensif empat keterampilan, yaitu tes tulis, membaca, menyimak, dan berbicara. Evaluasi dalam bentuk tes ini digunakan untuk mengukur peningkatan kemampuan berbahasa mereka ketika tengah semester dan akhir semester. Instrument evaluasi disusun oleh tim guru berdasarkan materimateri yang telah dicapai oleh mahasiswa asing selama pembelajaran.

Sementara itu bentuk evaluasi pembelajaran berbasis nontes berupa kumpulan portofolio, unjuk kerja, dan proyek akhir mahasiswa. Guru menggunakan kumpulan portofolio mahasiswa dalam bentuk tulisan catatan harian mahasiswa untuk mengontrol perkembangan tulisan narasi dan kosa kata yang digunakan oleh mahasiswa setiap hari. Bentuk evaluasi nontes ini dinilai efektif oleh guru dalam menilai perkembangan kosa kata mereka. Pada evaluasi nontes yang berupa unjuk kerja, mahasiswa dituntut untuk mempraktikan secara langsung setiap kegiatan pembelajaran yang berdasarkan 
teknik bermain peran agar guru dengan mudah memperoleh nilai secara nyata sesuai dengan kemampuan mahasiswa asing tersebut. Terakhir adalah evaluasi nontes yang berupa proyek akhir dalam bentuk penelitian tingkat dasar yang dilakukan oleh mahasiswa dengan cara memilih topik favorit sesuai dengan peminatan dan latar belakang tujuan mereka belajar. Proyek akhir ini merupakan bentuk evaluasi pembelajaran yang bertujuan untuk menyiapkan mahasiswa asing tingkat mahir rendah dalam memahami konteks kebahasaan yang bersifat resmi dan akademisi. Proyek akhir mahasiswa ini juga sekaligus menjadi tolok ukur ketercapaian semua tujuan pada level mahir rendah dan menuju pada level mahir tengah atau bahkan level mahir atas.

\section{PENUTUP}

Pemaparan dari hasil penelitian dan pembahasan menghasilkan kesimpulan dalam mengembangkan desain pembelajaran BIPA Darmasiswa pada pembelajar tingkat mahir rendah dapat mempertimbangkan keempat faktor sebagai berikut, yaitu (1) karakteristik pada pembelajar Darmasiswa tingkat mahir rendah, (2) menganalisis kebutuhan mahasiswa Darmasiswa tingkat mahir renda, (3) penggunaan teknik pembelajaran mahasiswa di kelas Darmasiswa tingkat mahir rendah, dan (4) bentuk evaluasi pembelajaran yang digunakan pada kelas mahir rendah. Keempat faktor tersebut merupakan unsur inti yang bisa disiapkan dalam rancangan pengembangan kelas BIPA pada tingkat mahir rendah dalam program BIPA Darmasiswa maupun dalam program BIPA yang lainnya. Akan tetapi, tetap harus memperhatikan jenis program dan pembelajar BIPA.

Peneliti selanjutnya juga dapat mengembangkan salah satu faktor tersebut sebagai kajian lanjutan pada penelitian pengembangan desain pembelajaran BIPA selanjutnya. Dengan demikian dapat disimpulkan bahwa pengembangan desain pembelajaran model ASSURE dapat diterapkan untuk mengembangkan desain pembelajaran BIPA pada tingkat mahir rendah.

\section{DAFTAR PUSTAKA}

Kusmiatun, Ari. (2016). Mengenal BIPA dan Pembelajarannya. Yogyakarta: K Media

Lestyarini, Beniati. (2012). Model Sintetik dan Analitik Berbasis Karakter Indonesia dalam Pembelajaran BIPA di Era Global. Makalah disajikan pada seminar Internasional ASILE 2012 dan KIPBIPA VIII LTCUKSW. Salatiga: Language Training Center Satya Wacana Christian University.

Miles, B.M. \& Huberman, A.M. 2007. Analisis Data Kualitatif: Buku Sumber Metode-Metode Baru. Jakarta: Universitas Indonesia Press.

Lestyarini, Beniati. (2012). Model Sintetik dan Analitik Berbasis Karakter Indonesia dalam Pembelajaran BIPA di Era Global. Makalah disajikan pada seminar Internasional ASILE 2012 dan KIPBIPA VIII LTCUKSW. Salatiga: Language Training Center Satya Wacana Christian University.

Muliastuti, Liliana. (2016). BIPA Pendukung Internasionalisasi Bahasa Indonesia. Makalah disajikan pada seminar Nasional Politik Bahasa di Universitas Tidar Magelang. Magelang: Untidar.

Ruskhan, Abdul Gaffar. (2007). Pemanfaatan Keberagaman Budaya Indonesia dalam Pengajaran Bahasa 
Jurnal Filsafat, Sains, Teknologi, dan Sosial Budaya

Volume 26, Nomor 2, Oktober 2020

Indonesia bagi Penutur Asing (BIPA).

Makalah disajikan dalam Seminar

Pengajaran Bahasa Indonesia

Pertemuan Asosiasi Jepang-Indonesia

di Nanzan Gakuen Training

Center. Nagoya: Pusat Bahasa

Departemen Pendidikan Nasional

Republik Indonesia.

Suyitno, Imam. (2007). Pengembangan

Bahan Ajar Bahasa Indonesia untuk

Penutur Asing (BIPA) berdasarkan

Hasil Analisis Kebutuhan Belajar.

Jurnal Ilmu Pengetahuan Budaya, 9

(1), pp. 62-78.

Suyitno, Imam. (2008). Norma Pedagogis

dan Analisis Kebutuhan Belajar

dalam Pembelajaran Bahasa Indonesia

untuk Penutur Asing (BIPA). Diksi, 15

(1), pp: 111-119.

Ulumuddin, Arisul, Agus Wismanto. (2014).

Bahan Ajar Bahasa Indonesia Ranah

Sosial Budaya bagi Penutur Asing

(BIPA). Jurnal Sasindo Pendidikan

Bahasa dan Sastra Indonesia, 2 (1), pp.

15-35. 